\title{
A Comparative Analysis of NZEB Energy Performance Requirements for Residential Buildings in Denmark, Estonia and Finland
}

\author{
Raimo Simson ${ }^{1,3 *}$, Kirsten Engelund Thomsen ${ }^{4}$, Kim Bjarne Wittchen ${ }^{4}$ and Jarek Kurnitski ${ }^{2,3}$ \\ ${ }^{1}$ Tallinn University of Technology, Department of Civil Engineering and Architecture, 19086 Tallinn, Estonia \\ ${ }^{2}$ Tallinn University of Technology, Smart City Centre of Excellence, Ehitajate tee 5, 19086 Tallinn, Estonia \\ ${ }^{3}$ Aalto University, Department of Civil Engineering, FI-00076 Aalto, Finland \\ ${ }^{4}$ Aalborg University, Department of the Built Environment, 2450 Copenhagen SV, Denmark
}

\begin{abstract}
Direct comparison of building energy performance levels between countries is usually not possible due to differences in climatic conditions, calculation methods, primary energy (PE) weighing factors and input data. This paper aims to analyse performance requirements and calculation methodology for residential Nearly Zero Energy Buildings (NZEBs) in Oceanic and Nordic climate zone countries according to European Commission (EC) recommended values, focusing on Denmark, Estonia, and Finland. Performance levels for each country are compared with European Commission (EC) recommended values (EU 2016/1318) using normalization and benchmarking through detailed computer simulations. The study is based on two representative buildings: a Danish single-family house and an Estonian apartment building, both designed to meet national NZEB requirements. The buildings were modelled using national and standardized (EN 16798-1:2019) methodologies, including country-specific climate and input data. The simulated performances were compared with EC threshold values, modified, and re-calculated to meet the NZEB PE targets of each country. To match the recommended energy performance, on-site renewable energy production using photovoltaic panels was increased or decreased accordingly. Results show that Estonian requirements for NZEB fulfil the EC NZEB recommendation. In the warmer, Oceanic climate zone it was however impossible to fulfil EC NZEB even with Estonian NZEB. This indicates that PE recommendations are too strict for colder Oceanic locations, represented in this paper by the Copenhagen climate.
\end{abstract}

\section{Introduction}

In heating dominated countries, the design of building envelope as well as ventilation and heating systems require higher attention in design practices to provide good indoor climate at low energy consumption [1]. There are many policies and programmes adopted in the EU which produce standards and regulations to impose increasingly stringent requirements to buildings in order to reduce carbon emissions and combat climate change [2].

In the recast of Energy Performance of Buildings Directive (EPBD) [3], the term Nearly Zero-Energy Building (NZEB) was introduced as a "building that has a very high energy performance and the nearly zero or very low amount of energy required should be covered to a very significant extent by energy from renewable sources, including energy from renewable sources produced on-site or nearby" (Art. 2). NZEB thus has not a single definite energy performance threshold. The EC recommendation states that "There cannot be a single level of ambition for NZEB across the EU. Flexibility is needed to account for the impact of climatic conditions on heating and cooling needs and on the costeffectiveness of packages of energy efficiency and renewable energy sources measures" [4], meaning that each country is free to implement its own NZEB levels and performance assessment methodology. As of January 2019, all new public buildings and from January 2021 all other new buildings should reach the NZEB target as defined at national level.

Table 1. EC recommendation on energy use in residential buildings [4]. PE is Primary Energy and RES is Renewable Energy Sources.

\begin{tabular}{|c|c|c|c|c|}
\hline \multirow[b]{3}{*}{$\begin{array}{c}\text { Energy } \\
\text { use }\end{array}$} & \multicolumn{4}{|c|}{ Zone } \\
\hline & $\begin{array}{l}\text { Medi- } \\
\text { terranean } \\
\text { Zone } 1\end{array}$ & $\begin{array}{c}\text { Oceanic } \\
\text { Zone } 4\end{array}$ & $\begin{array}{c}\text { Continen- } \\
\text { tal } \\
\text { Zone } 3\end{array}$ & $\begin{array}{l}\text { Nordic } \\
\text { Zone } 5\end{array}$ \\
\hline & $\begin{array}{c}\text { Catania, } \\
\text { Athens, } \\
\text { Larnaca, } \\
\text { Luga, } \\
\text { Seville, } \\
\text { Palermo }\end{array}$ & $\begin{array}{c}\text { Paris, } \\
\text { Amsterdam, } \\
\text { Berlin, } \\
\text { Brussels, } \\
\text { Copen- } \\
\text { hagen, } \\
\text { Dublin, } \\
\text { London, } \\
\text { Prague, } \\
\text { Warszawa }\end{array}$ & $\begin{array}{c}\text { Budapest, } \\
\text { Bratislava, } \\
\text { Ljubljana, } \\
\text { Milan, } \\
\text { Vienna }\end{array}$ & $\begin{array}{c}\text { Stock- } \\
\text { holm, } \\
\text { Tallinn, } \\
\text { Helsinki, } \\
\text { Riga, } \\
\text { Gdansk, } \\
\text { Tovarene }\end{array}$ \\
\hline $\begin{array}{c}\text { Net PE } \\
\mathrm{kWh} /\left(\mathrm{m}^{2} \cdot \mathrm{y}\right)\end{array}$ & $0-15$ & $15-30$ & $20-40$ & $40-65$ \\
\hline $\begin{array}{c}\text { PE w/o } \\
\text { RES } \\
\mathrm{kWh} /\left(\mathrm{m}^{2} \cdot \mathrm{y}\right)\end{array}$ & $50-65$ & $50-65$ & $50-70$ & $65-90$ \\
\hline $\begin{array}{c}\text { on-site } \\
\text { RES } \\
\mathrm{kWh} /\left(\mathrm{m}^{2} \cdot \mathrm{y}\right)\end{array}$ & 50 & 35 & 30 & 25 \\
\hline
\end{tabular}

* Corresponding author: raimo.simson@taltech.ee 
The EC has set recommended benchmarks for energy performance of NZEB for four EU climatic zones [4]: Mediterranean, Oceanic, Continental and Nordic (Table 1). For residential buildings, most Member States (MS) aim to have a primary energy (PE) use not higher than $50 \mathrm{kWh} /\left(\mathrm{m}^{2} \cdot \mathrm{y}\right)$. The maximal PE use ranges between $31-37.5 \mathrm{kWh} /\left(\mathrm{m}^{2} \cdot \mathrm{y}\right)$ in Denmark or 33 $\mathrm{kWh} /\left(\mathrm{m}^{2} \cdot \mathrm{y}\right)$ in Croatia (Littoral) and $95 \mathrm{kWh} /\left(\mathrm{m}^{2} \cdot \mathrm{y}\right)$ in Latvia. Several countries (Belgium (Brussels), Estonia, France, Ireland, Slovakia, United Kingdom, Bulgaria, Denmark, Croatia (Continental), Malta, Slovenia) aim at 45 or $50 \mathrm{kWh} /\left(\mathrm{m}^{2} \cdot \mathrm{y}\right)$. Aside from the different $\mathrm{PE}$ requirements, each country has implemented its own methodology for PE calculation making comparison of the requirements difficult.

A recent study by Ahmed et al. [5] was conducted to compare the differences in energy performance requirements of office buildings in Japan and in select European countries. The results of the study emphasised the differences in climate and PE factors, regarding different heat sources, and demonstrated the relative strictness of the performance levels.

This paper aims to analyse performance requirements and calculation methodology for residential NZEBs in Oceanic and Nordic, climate zone countries, focusing on Denmark, Estonia, and Finland. The results highlight the impact of climatic conditions, importance of passive building design, differences in methodological framework and variable strictness of the energy performance requirements between the countries.

The study is part of a broader project is to establish a collection of examples of NZEBs in the five countries Denmark, Estonia, Finland, Latvia and Lithuania and share experiences and inspire to further deployment of architectural attractive and technical successful NZEBs in the region. To ensure successful deployment of NZEB, there is a crucial need for examples with reasonable priced, efficient technical solution. In this way, it is possible to support the building sectors in countries with comparable climate conditions to build robust NZEBs. Additionally, it is important to investigate the technical solutions used in NZEBs as it represents different boundary conditions for making NZEBs. Learning from existing examples will provide valuable information for designers to avoid falling into known pitfalls and to utilise knowledge about good, affordable solutions.

\section{Methods}

The analysis of the energy performance requirements and calculation methodology was divided into following parts:

- Comparing national requirements by the key numbers, energy performance calculation specifics, input data and methodological differences.

- Analysing the climatic data used in the energy calculations in each country. This was done by comparing the hourly average outdoor temperatures extracted from Test Reference Years (TRYs).
- Choosing residential reference buildings that would comply with the national requirements for NZEB one single-family building and one apartment building. Creating simulation models of the buildings.

- Comparing results from monthly quasi-steady state calculations and hourly dynamic calculations.

- Calculating building performance as required by the national regulations of each country.

- Calculating building performance using national TRY weather and input data for standard use from EN 16798-1:2019 [6] to fulfil the EC PE recommendation for NZEB [4].

- Comparing and analysing the results to quantify the impact of climatic conditions, methodological differences, and strictness of the NZEB requirements.

If proven necessary, renewable energy production through photovoltaic (PV) panels were changed to achieve the desired goal (e.g., NZEB performance level). Weather data, occupancy and usage rates, internal heat gains, electricity consumption by lighting, appliances and distribution losses of the HVAC systems were changed accordingly to the values specified in the national calculation methods. The changes, if present, have been described in the relevant sections of the paper.

\subsection{National NZEB requirements and calculation methods}

To achieve the EPBD targets EU Member States (MS) have implemented requirements and calculation procedures for estimating energy consumption of a new building. These methods vary in terms of usage profiles, energy systems and include different aspects of building energy use. Table 2 presents PE factors for energy carriers used in EC recommendations and national energy performance calculations in Estonia, Denmark, and Finland. Overview of the energy flows included in the national calculations and the allowed maximum PE values to comply with NZEB requirements are given in Table 3. The main parameters which are used in the energy calculations are compared in Table 4. The main outlines, differences and specifics of the requirements are presented and discussed in the next sub-sections, divided by the analysed countries.

Table 2. PE factors used in European Commission recommendations (EC), Estonia (EE) [7], Denmark (DK) [8] and Finland (FI) [9].

\begin{tabular}{|c|c|c|c|c|}
\hline \multirow{2}{*}{$\begin{array}{c}\text { Energy } \\
\text { carrier }\end{array}$} & \multicolumn{4}{|c|}{ PE factors, - } \\
\cline { 2 - 5 } & EC & DK & EE & FI \\
\hline Electricity & 2.3 & 1.9 & 2.0 & 1.2 \\
\hline $\begin{array}{c}\text { District } \\
\text { heating }\end{array}$ & 1.3 & 0.85 & 0.65 & 0.5 \\
\hline \begin{tabular}{c} 
Natural gas \\
\hline
\end{tabular} & 1.1 & 1.0 & 1.0 & 1.0 \\
\hline
\end{tabular}


Table 3. National and EC NZEB requirements and energy flows included in the PE calculations [4, 7-9].

\begin{tabular}{|c|c|c|c|}
\hline & \multirow{2}{*}{ Included energy flows } & \multicolumn{2}{|c|}{ PE requirement for NZEB, $\mathrm{kWh} /\left(\mathrm{m}^{2} \cdot \mathrm{y}\right)$} \\
\hline & & Single-family house & Apartment building \\
\hline EC recommendation & HVAC, DHW, auxiliary & \multicolumn{2}{|c|}{$\begin{array}{l}\text { Oceanic: 15-30 (incl. 35 RES) } \\
\text { Nordic: 40-65 (incl. 25 RES) }\end{array}$} \\
\hline Estonia, requirement & $\begin{array}{l}\text { HVAC, DHW, auxiliary, } \\
\text { lighting and appliances }\end{array}$ & $\begin{array}{c}145(165)^{(*)}\left(\mathrm{A}_{\text {net }}<120 \mathrm{~m}^{2}\right) \\
120(140)^{(*)}\left(120 \leq \mathrm{A}_{\text {net }} \leq 220 \mathrm{~m}^{2}\right) \\
100(120)^{(*)}\left(\mathrm{A}_{\text {net }}>220 \mathrm{~m}^{2}\right)\end{array}$ & $105(125)^{(*)}$ \\
\hline Denmark, requirement & HVAC, DHW, auxiliary & $30+1000 / A_{\text {gross }}$ & $30+1000 / \mathrm{A}_{\text {gross }}$ \\
\hline Finland, requirement & $\begin{array}{l}\text { HVAC, DHW, auxiliary, } \\
\text { lighting and appliances }\end{array}$ & $\begin{array}{c}200-0.6 \mathrm{~A}_{\text {net }}\left(50<\mathrm{A}_{\text {net }} \leq 150 \mathrm{~m}^{2}\right) \\
116-0.04 \mathrm{~A}_{\text {net }}\left(150<\mathrm{A}_{\text {net }} \leq 600 \mathrm{~m}^{2}\right) \\
92\left(\mathrm{~A}_{\text {net }}>600 \mathrm{~m}^{2}\right)\end{array}$ & 90 \\
\hline
\end{tabular}

${ }^{(*)}$ Additional PE requirement without accounting RES

Table 4. Input data for residential buildings energy performance calculation according to EU [6] and national (DK [8], EE [7], FI [9]) building regulations.

\begin{tabular}{|c|c|c|c|c|}
\hline Input parameter, [unit] & $\mathbf{E U}$ & DK & $\mathbf{E E}$ & FI \\
\hline Heating set point, ${ }^{\circ} \mathrm{C}$ & 20 & 20 & 21 & 21 \\
\hline Ground temperature (for heat loss calc), ${ }^{\circ} \mathrm{C}$ & calculated & 10 & calculated & calculated \\
\hline Internal heat gains: occupants, $\mathrm{W} / \mathrm{m}^{2}{ }^{(*)}$ & $\begin{array}{l}2.8(\mathrm{SFH}) \\
4.2(\mathrm{APT})\end{array}$ & $\begin{array}{c}1.5, \max 360 \mathrm{~W} \\
\text { per unit }\end{array}$ & $\begin{array}{c}3.0\left(\text { SFH: } \mathrm{A}_{\text {net }}<120 \mathrm{~m}^{2}\right) \\
2.0\left(\mathrm{SFH}: 120 \leq \mathrm{A}_{\text {net }} \leq 220 \mathrm{~m}^{2}\right) \\
1.4\left(\mathrm{SFH}: \mathrm{A}_{\text {net }}>220 \mathrm{~m}^{2}\right) \\
3.0(\mathrm{APT})\end{array}$ & $\begin{array}{l}2.0(\mathrm{SFH}) \\
3.0(\mathrm{APT})\end{array}$ \\
\hline Internal heat gains: appliances, $\mathrm{W} / \mathrm{m}^{2(*)}$ & $\begin{array}{l}2.4(\mathrm{SFH}) \\
3.0(\mathrm{APT})\end{array}$ & $3.5^{(* *)}$ & $\begin{array}{c}3.0\left(\text { SFH: } \mathrm{A}_{\text {net }}<120 \mathrm{~m}^{2}\right) \\
2.4\left(\mathrm{SFH}: 120 \leq \mathrm{A}_{\text {net }} \leq 220 \mathrm{~m}^{2}\right) \\
2.0\left(\mathrm{SFH}: \mathrm{A}_{\text {net }}>220 \mathrm{~m}^{2}\right) \\
3.0 \text { APT }\end{array}$ & $\begin{array}{l}3.0(\mathrm{SFH}) \\
4.0(\mathrm{APT})\end{array}$ \\
\hline Internal heat gains: lighting, $\mathrm{W} / \mathrm{m}^{2(*)}$ & $\begin{array}{l}6.0 \text { (SFH) } \\
9.0(\mathrm{APT})\end{array}$ & $\begin{array}{l}\text { Included in } \\
\text { appliances }\end{array}$ & $\begin{array}{l}6.0(\mathrm{SFH}) \\
8.0(\mathrm{APT})\end{array}$ & $\begin{array}{l}6.0(\mathrm{SFH}) \\
9.0(\mathrm{APT})\end{array}$ \\
\hline Occupancy usage rate & 0.6 & 1.0 & 0.6 & 0.6 \\
\hline Lighting usage rate & 0.1 & \multirow{2}{*}{1.0} & 0.1 & 0.1 \\
\hline Appliances usage rate & 0.6 & & 0.6 & 0.6 \\
\hline Usage time, $\mathrm{h}$ per day/days per week & $24 / 7$ & $24 / 7$ & $24 / 7$ & $24 / 7$ \\
\hline DHW use, $\mathrm{kWh} /\left(\mathrm{m}^{2} \cdot \mathrm{y}\right)^{(*)}$ & 25 & $\begin{array}{l}16.0(\mathrm{SFH})^{(* * *)} \\
13.4(\mathrm{APT})^{(* * *)}\end{array}$ & $\begin{array}{c}\left.30 \text { (SFH: } \mathrm{A}_{\text {net }}<120 \mathrm{~m}^{2}\right) \\
\left.25 \text { (SFH: } 120 \leq \mathrm{A}_{\text {net }} \leq 220 \mathrm{~m}^{2}\right) \\
\left.20 \text { (SFH: } \mathrm{A}_{\text {net }}>220 \mathrm{~m}^{2}\right) \\
30 \text { (APT) }\end{array}$ & 35 (APT) \\
\hline Ventilation airflow rate, $1 /\left(\mathrm{s} \cdot \mathrm{m}^{2}\right)^{(*)}$ & 0.5 & 0.30 (minimum) & $\begin{array}{c}0.50 \text { central AHU } \\
0.42 \mathrm{DCV}\end{array}$ & $\begin{array}{l}0.4(\mathrm{SFH}) \\
0.5(\mathrm{APT}) \\
0.4 \mathrm{DCV}\end{array}$ \\
\hline $\begin{array}{l}\text { Ventilation operation time, } \\
\text { h per day / days per week }\end{array}$ & $24 / 7$ & $24 / 7$ & $24 / 7$ & $24 / 7$ \\
\hline DH sub-station efficiency, - & 1.00 & $\begin{array}{l}\text { Losses are } \\
\text { calculated }\end{array}$ & 0.90 & 0.97 \\
\hline Radiator heating efficiency, - & 0.91 & $\begin{array}{l}\text { Distribution } \\
\text { losses } \\
\text { calculated }\end{array}$ & 0.97 & 0.85 \\
\hline Underfloor heating efficiency, - & 0.91 & $\begin{array}{l}\text { Distribution } \\
\text { losses } \\
\text { calculated }\end{array}$ & $\begin{array}{l}0.85 \text { slab on ground } \\
1.0 \text { internal floor }\end{array}$ & $\begin{array}{l}0.8 \text { slab on ground } \\
0.85 \text { internal floor }\end{array}$ \\
\hline
\end{tabular}

${ }^{(*)}$ gross heated floor area in case of DK, net heated floor area in case of EU, EE and FI.

${ }^{(* *)}$ including lighting. Energy need is not included in the energy frame but contributes to heating of the building. Minimum $210 \mathrm{~W}$ and maximum $840 \mathrm{~W}$ per unit (dwelling).

${ }^{(* *)}$ energy need depends on the efficiency of the heat supply for DHW and is calculated based on an annual consumption of DHW equal to $250 \mathrm{~L} /\left(\mathrm{m}^{2} \cdot \mathrm{y}\right)$.

SFH - Single-family house; APT - Apartment building; DCV - Apartment-based demand-controlled ventilation unit 


\subsubsection{Estonia}

The energy efficiency requirements for buildings in Estonia are defined through the maximum allowed PE consumption and are set in the national regulation [7]. The energy performance of a building is presented as Energy Performance Indicator (EPI) value in $\mathrm{kWh} /\left(\mathrm{m}^{2} \cdot \mathrm{y}\right)$ and the allowed EPI value limit depends on the building type. The EPI value incorporates the energy use for space heating, space cooling, domestic hot water (DHW) production, lighting, appliances, and auxiliary devices, i.e. fans and pumps. The EPI value calculation follows the system boundaries of REHVA's definition [10], but only on-site produced energy which is consumed by the building systems is taken into the account and is subtracted from the delivered energy [11]. Exported energy is not accounted when calculating the EPI value.

The calculation methodology includes the following factors [11]:

- Thermal transmittance of building envelope, linear and point thermal transmittance of thermal bridges, and air leakage

- Indoor air temperature

- DHW need

- Ventilation

- Thermal loads from occupant, light, appliances, hot water, and solar heat

- Thermal and electrical energy use for spaces heating, ventilation heating, DHW system

- Electricity use for ventilation system (fan and pump), lighting, equipment

- On-site energy generation: with PV panels, solar thermal collectors, wind turbines.

Heat recovery from wastewater and/or ventilation. Heat losses from building envelope, thermal bridges, ventilation heat losses, system efficiency calculation method, and onsite electricity production are accounted for using specific pre-determined values given in detail in the regulation [11]. Also, a separate dynamic simulation is required to prove compliance with summer thermal comfort criteria.

The EPI value is calculated according to the following equation [11]:

$$
E P I=\frac{\sum_{i}\left(Q_{i} \cdot f_{i}\right)}{A_{\text {net }}}
$$

where, $Q_{i}$ is the annual energy use for electricity, fuel, district heating, district cooling etc, $[\mathrm{kWh} / \mathrm{y}], f_{i}$ is the $\mathrm{PE}$ factor for the corresponding energy carrier, [dimensionless] and $A_{n e t}$ is the net heated building area, $\left[\mathrm{m}^{2}\right]$. The latter equation accounts for the total energy consumed by the building, which includes also the consumed renewable energy, which is produced on-site.

The Estonian building regulation gives an additional requirement for the buildings: maximum allowed PE use without accounting (subtracting) the onsite produced and consumed renewable energy from the building's total energy use. The requirement is defined as "EPI B" value and is calculated according to the following equation (for a building with on-site renewable electricity production):

$$
\text { EPI } B=\frac{\sum_{j}\left(Q_{j} \cdot f_{j}\right)+\left(Q_{c, e l}+Q_{p r, c, e l}\right) \cdot f_{e l}}{A_{\text {net }}}
$$

where, $Q_{j}$ is the annual energy use, except electricity, $[\mathrm{kWh} / \mathrm{y}], f_{j}$ is the $\mathrm{PE}$ factor for the corresponding energy carrier, [dimensionless], $Q_{c, e l}$ is the annual electricity use, $[\mathrm{kWh} / \mathrm{y}], Q_{p r, c, e l}$ is the fraction of the annual produced electricity which is consumed by the building, $[\mathrm{kWh} / \mathrm{y}], \quad f_{e l}$ is the PE factor for electricity, [dimensionless] and $A_{\text {net }}$ is the net heated building area, $\left[\mathrm{m}^{2}\right]$. The fraction of locally produced electricity accounted in the PE calculations is $45 \%$ for single family buildings with $A_{\text {net }}$ lower than $120 \mathrm{~m}^{2}, 40 \%$ for detached houses with $A_{\text {net }}$ between $120 \mathrm{~m}^{2}$ and $220 \mathrm{~m}^{2}$ including terraced houses, and 55\% for apartment buildings.

\subsubsection{Finland}

The maximal PE requirement for Finnish buildings is set in the Finnish regulation [12]. The EPI of a building, presented as PE value given in $\mathrm{kWh} /\left(\mathrm{m}^{2} \cdot \mathrm{y}\right)$ (net heated area), is either a fixed value or depends on building type, function, and geometry. The energy performance calculation methodology has many similarities with the Estonian methodology, namely with included energy flows, input data and required calculation procedures. The EPI number incorporates the energy use for space heating, space cooling, DHW, lighting, appliances, and auxiliary devices, i.e. fans and pumps. The EPI also follows the system boundaries of REHVA [10] definition, and similarly to Estonian methodology only onsite renewable energy used in the building is taken into the account, reducing the delivered energy. Equation for the EPI is the same as used in the Estonian regulation, given in previous section as equation (1).

Heat losses from building facade, thermal bridges, ventilation heat losses, system efficiency calculation method, onsite electricity production are given in details in the national building code guide [13].

Energy use for lighting and appliances is taken from Finnish national building regulation guide [13] and it will be multiplied with the national PE factor to obtain the PE use for lighting and appliance. The net heating energy for DHW is given as a default value.

\subsubsection{Denmark}

The Danish Building Regulations 2018 (BR18) [8] sets minimum energy performance requirements for all types of new buildings. In addition to the minimum requirements, the BR18 also sets requirements for a voluntary low-energy class.

The Danish minimum energy performance also sets the limit in terms of maximum allowed PE as is the case in Estonian and Finnish requirements. The PE need for a building. includes also similarly to EE and FI methodology, thermal bridges, solar gains, shading, infiltration, ventilation, heat recovery, cooling, boiler and heat pump efficiency, electricity for operating the building and lighting, the latter in contrast to Estonian

\footnotetext{
*Corresponding author: raimo.simson@taltech.ee
} 
and Finnish methodology is accounted for nonresidential buildings only. Additionally, the Danish calculation includes specific "sanctions" for overheating, in which case a penalty is included as a fictive energy need, equal to the energy need (including $\mathrm{PE}$ factor of electricity) by an imaginary mechanical cooling system with a COP of 3.0 , in order to keep the indoor temperature at $26^{\circ} \mathrm{C}$. This additional energy need is included in the calculated overall energy need of the building by the monthly-based compliance-checking tool, "Buildings energy demand - Be18" [14].

On-site produced renewable energy is also included in the calculation. However, for all buildings, the maximum local electricity production to be factored in from RES, e.g. PV panels and wind turbines corresponds to a reduction of the need for supplied PE of $25 \mathrm{kWh} / \mathrm{m}^{2}$ per year in the energy performance framework. Additionally, to the mandatory requirement, the EPI threshold for the voluntary Low energy class is given as:

$27 \mathrm{kWh} /\left(\mathrm{m}^{2} \cdot \mathrm{y}\right)$ for residential buildings, and

$33 \mathrm{kWh} /\left(\mathrm{m}^{2} \cdot \mathrm{y}\right)$ for non-residential buildings.

Buildings that comply with the BR18 and the voluntary low-energy class must prove that they have a good thermal indoor climate during hot periods. The indoor temperature in residential buildings must not exceed $27^{\circ} \mathrm{C}$ for more than 100 hours per year, and $28^{\circ} \mathrm{C}$ for more than 25 hours per year. This can be done either through "Be18" or via a dynamic simulation tool. In non-residential buildings, the building owner decides the temperature limits, and summer comfort must be proven using a dynamic simulation tool. Additionally, and in contrast to the Estonian and Finnish regulations, the Danish Building Regulations include specific requirements for a wide range of technical building systems. There are specific energy-related requirements for e.g. ventilation units, combined heat \& power appliances, oil/gas/biomass boilers, heat pumps and circulation pumps for installations.

Individual building envelope elements must be insulated to a level ensuring that the dimensioning heat losses through them do not exceed pre-defined values. Calculation of heat-loss coefficients must be made in accordance with Danish standards.

Energy need for DHW is based on a standard use of hot water $\left(250 \mathrm{~L} /\left(\mathrm{m}^{2} \cdot \mathrm{y}\right)\right.$ in residential buildings $)$ and calculated depending on the efficiency of the technical system installed in the building. The national standard excludes lighting and electricity from private appliances from the energy performance calculation in residential buildings.

\subsection{Reference buildings}

Two residential buildings were selected for the analysis: a single storey detached house and a multi storey apartment building. Both buildings were initially designed as NZEB according to its nation of origins: the single-family house in Denmark and the apartment building in Estonia. The buildings are representative examples of new NZEBs with modern designs and technical solutions.

\subsubsection{Single-family house}

For the reference single family house, a typical Danish single-storey house was chosen (Figure 1). The net heated area of the building is $138 \mathrm{~m}^{2}$ and gross heated area $165 \mathrm{~m}^{2}$. The Energy Performance Certificate (EPC) was acquired for the building in 2017 with a national A2020 rating, categorizing the building as "low energy building", exceeding the requirements for NZEB due to PV. Roof construction towards unheated attic is isolated by $400 \mathrm{~mm}$ mineral wool with a total U-value $0.09 \mathrm{~W} /\left(\mathrm{m}^{2} \cdot \mathrm{K}\right)$. External walls are constructed by a masonry external leaf and a lightweight concreate inner leaf. The total wall thickness is $36 \mathrm{~cm}$, and the cavity is insulated with mineral wool with an average U-value of $0.29 \mathrm{~W} /\left(\mathrm{m}^{2} \cdot \mathrm{K}\right)$. This is a traditional external wall construction where masonry is the predominant building material for external walls. The slab on ground construction is made of concrete with $275 \mathrm{~mm}$ EPS insulation, U-value $0.12 \mathrm{~W} /\left(\mathrm{m}^{2} \cdot \mathrm{K}\right)$. Joints between external walls and foundation are made of lightweight cinder blocks with centre insulation. Joints for windows and exterior doors are well insulated. The line-loss coefficients are 0.17 and $0.03 \mathrm{~W} /(\mathrm{m} \cdot \mathrm{K})$ respectively. Windows are with 2-pane low-energy glazing with an overall U-value of $1.3-1.5 \mathrm{~W} /\left(\mathrm{m}^{2} \cdot \mathrm{K}\right)$ and a g-value for the glazing of 0.63 . Envelope air permeability $\mathrm{q}_{50} \leq 1.0$ $\mathrm{m}^{3} / \mathrm{h}$ per $\mathrm{m}^{2}$ of external heated gross floor area at $50 \mathrm{~Pa}$ pressure difference.

Heating and DHW is provided from an efficient ground source heat pump and space heating is delivered by a floor heating system. The house is mechanically ventilated by balanced ventilation system with a heat recovery $(88 \%)$ unit located at the attic. The ventilation rate is approx. 0.5 air changes per hour. The average specific fan power (SFP) of the systems is $1.0 \mathrm{~kJ} / \mathrm{m}^{3}$ (national requirement). Ground source combined (heat and hot water) heat pump with a Coefficient of Performance (COP) 3.58 and a nominal output of 5.21 $\mathrm{kW}$. Low temperature underfloor heating system is designed for water temperatures $40 / 30^{\circ} \mathrm{C}$. The ventilation system also uses water-based heating coils which are utilising low temperature water designed to $45 / 30^{\circ} \mathrm{C}$. Water is stored in a tank of 180 litres.

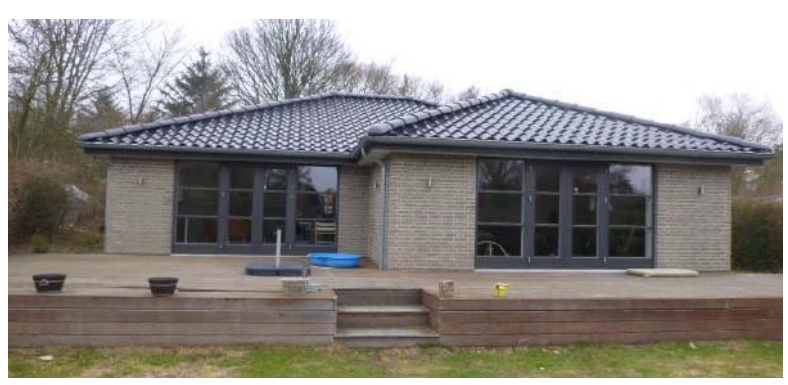

Figure 1. Photo of the reference single-family house (source: [15]). 
Hot water is also provided from the heat pump. The initial national energy performance calculation includes a default (standard) consumption of DHW equal to 250 litres per $\mathrm{m}^{2}$ heated gross floor area per year. Calculated energy need for DHW is based on the heat pump's efficiency. Internal heat loads from light and appliances are included as $3.5 \mathrm{~W} / \mathrm{m}^{2}$ heated gross floor area, but not part of the calculated energy need according to the Danish building regulations.

Additionally, the house is equipped with $24 \mathrm{~m}^{2}$ eastfacing PV panels with a tilt from horizontal of $25^{\circ}$. In the calculated energy performance, a maximum of 25 $\mathrm{kWh} /\left(\mathrm{m}^{2} \cdot \mathrm{y}\right)$ primary energy can be deducted from locally produced electricity (local PV, wind turbines and hydro power). Annual yield of the PV system is calculated to $2870 \mathrm{kWh}$ or $17.4 \mathrm{kWh} /\left(\mathrm{m}^{2} \cdot \mathrm{y}\right)$, equal to 25 $\mathrm{kWh} /\left(\mathrm{m}^{2} \mathrm{y}\right)$ primary energy. There is no distinguishing between exported or locally used electricity.

\subsubsection{Apartment building}

The reference apartment building has 4 residential floors, 1 commercial floor and an underground garage (Figure 2). The net heated area of the building is 4986 $\mathrm{m}^{2}$ and gross heated area $5626 \mathrm{~m}^{2}$. The architectural design utilizes a combination of passive cooling measures such as massive concrete envelope, optimal window sizes with low-E and optimal solar factor glazing together with shading balconies to minimize the risk for summertime overheating. Building envelope is constructed mostly from prefabricated concrete elements: with precast concrete sandwich panel external walls and hollow core concrete slabs.

External walls are insulated with $200 \mathrm{~mm}$ expanded polystyrene (EPS), with thermal transmittance (U) of $0.12 \mathrm{~W} /\left(\mathrm{m}^{2} \cdot \mathrm{K}\right)$ and roof with $250 \mathrm{~mm}$ polyisocyanurate (PIR) and $200 \mathrm{~mm}$ EPS, $\mathrm{U}=0.08 \mathrm{~W} /\left(\mathrm{m}^{2} \mathrm{~K}\right)$; floors with $200 \mathrm{~mm}$ (EPS), $\mathrm{U}=0.12 \mathrm{~W} /\left(\mathrm{m}^{2} \cdot \mathrm{K}\right)$. Thermal bridges have been minimized with optimized joints between construction elements, windows, and walls. Envelope air permeability q50 $\leq 1.5 \mathrm{~m}^{3} / \mathrm{h}$ per $\mathrm{m}^{2}$ of external walls at $50 \mathrm{~Pa}$ pressure difference. The windows have 3-pane glazing with low-E coatings and PVC-based frame. The total thermal transmittance of windows is $\leq 0.9$ $\mathrm{W} /\left(\mathrm{m}^{2} \cdot \mathrm{K}\right)$ with frames $\mathrm{U} \leq 1.0 \mathrm{~W} /\left(\mathrm{m}^{2} \cdot \mathrm{K}\right)$ and glazing $\mathrm{U} \leq 0.8 \mathrm{~W} /\left(\mathrm{m}^{2} \cdot \mathrm{K}\right)$ and the glazing solar factor $\mathrm{g}=0.55$. Heating energy is provided by district heating network and rooms are heated mostly with underfloor heating utilising low temperature supply water (installed power $90 \mathrm{~kW}$, water temperatures $+37 / 32^{\circ} \mathrm{C}$ ). Additionally, low temperature radiators are used in common spaces, e.g., hallways (installed power $13 \mathrm{~kW}$, water temperatures $\left.+55 / 40{ }^{\circ} \mathrm{C}\right)$.

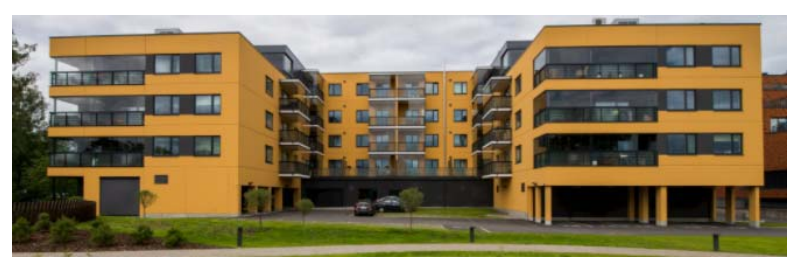

Figure 2. Photo of the reference apartment building (source: [16]).
The ventilation system consists of apartment-based ventilation units (51 pcs in total) utilizing rotary heat exchangers with high heat recovery efficiency of $80 \%$. The average specific fan power (SFP) of the systems is $1.5 \mathrm{~kW} /\left(\mathrm{m}^{3} / \mathrm{s}\right)\left[\mathrm{kJ} / \mathrm{m}^{3}\right]$. As additional energy efficiency measure, LED lighting fixtures are utilised in common spaces. To achieve national NZEB energy efficiency level, the roof of the building is filled with PV-panels for local renewable electricity production. The installed power of PV system is $65.4 \mathrm{~kW}$. Annual yield of the PV system is $57 \mathrm{MWh}_{\mathrm{e}}$.

According to the Estonian energy performance regulation, the building is required to meet the lowenergy class PE threshold (B-class) without accounting the renewable energy systems (RES) and NZEB (Aclass) including RES in the calculation.

\subsection{Energy need calculations and simulations}

The Danish regulations require new buildings energy consumption calculation using the calculation core of Be18 [14] (Figure 3).

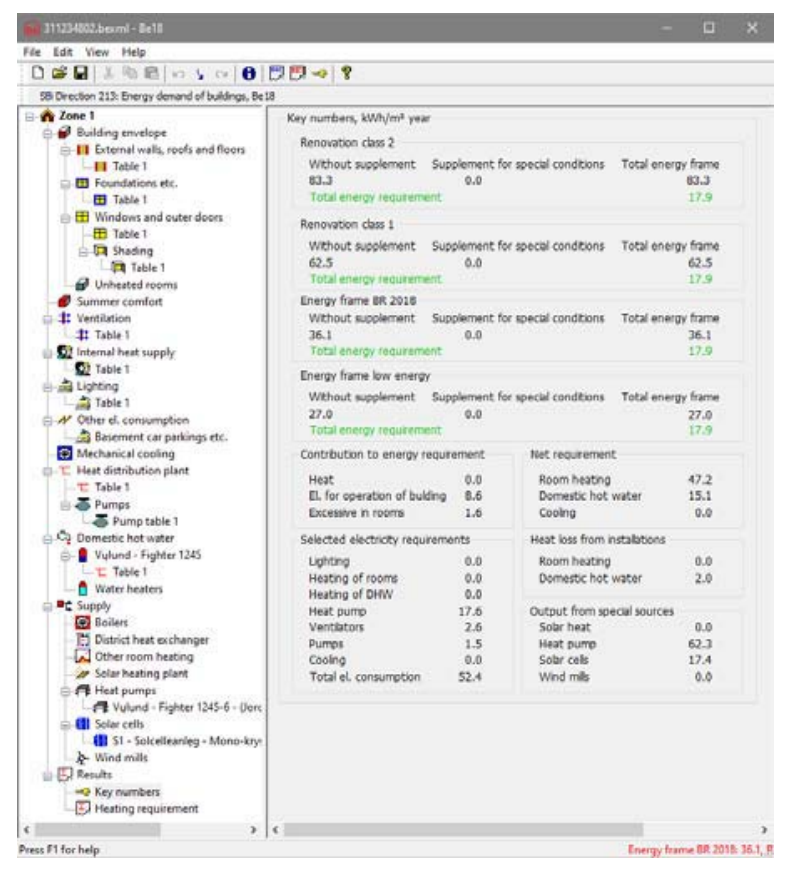

Figure 3. Screenshot - key indicators - of the Danish energy calculation software Be18 [14].

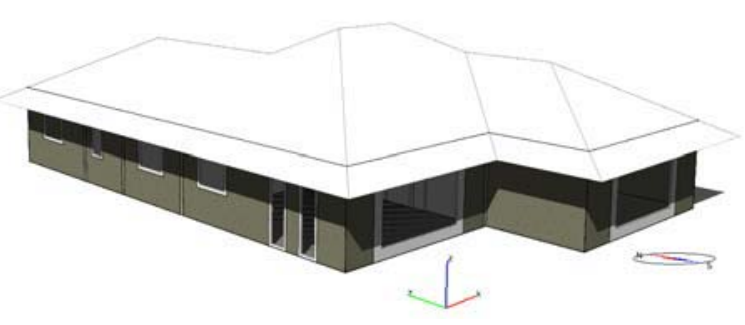

Figure 4. Simulation model of the reference single-family house. 


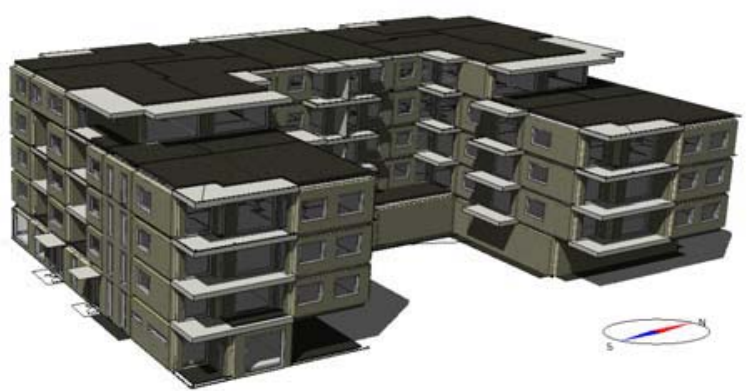

Figure 5. Simulation model of the reference apartment building.

The Be18 uses monthly quasi-steady state calculations and is developed to use for compliance check and energy certification of Danish buildings. Estonian and Finnish methodologies are similar, but require hourly dynamic simulations to estimate the energy use. IDA Indoor Climate and Energy (IDA ICE) [17] simulation software is used to calculate the energy need of the reference buildings. The simulation models of the reference buildings are shown in Figure 4 and Figure 5.

\section{Results and discussion}

There are many differences in calculation methodology, accounted energy flows, climate and building specific data for input to estimate energy consumption of buildings between the EC recommendations as well as between national building performance definitions and regulations. The latter makes it difficult to directly compare the required levels of energy performance in regard to NZEB definitions.

\subsection{Climatic differences}

The differences in climatic conditions can have substantial effect on building heating and cooling energy need. Figure 6 shows the minimum, maximum, $1^{\text {st }}$ and $3^{\text {rd }}$ quartile, average and median annual hourly average temperatures of the national Test Reference Years (TRYs) used in energy performance calculations in Denmark, Estonia, and Finland. The outdoor temperature averages are as follows: DK $8.1^{\circ} \mathrm{C}, \mathrm{EE}$ $5.7^{\circ} \mathrm{C}$ and FI $5.6^{\circ} \mathrm{C}$. Even as the dry bulb temperature does not reflect the full impact of climatic differences [5], it can be used to give some insight on the possible impact on building energy performance [18]. In reference, the heating degree days for base temperature of $17^{\circ} \mathrm{C}$ are $3410{ }^{\circ} \mathrm{Cd}$ for Danish TRY, $4518^{\circ} \mathrm{Cd}$ for Estonian TRY, and $4726^{\circ} \mathrm{Cd}$ for Finnish TRY.

Figure 7 presents the energy need for heating and cooling for different scenarios in case of the singlefamily house. To render the results comparable, in Danish cases also net heated area instead of gross, is used. The first three cases (1-3) show the results for energy calculations as required by the national building regulations, that is, with the country-specific TRY climate and input data. The following three cases show calculation results from EU standardised simulations, only changing the TRY. As can be seen from the calculated energy need, the impact of input data, including temperature set-points, usage rates, internal heat gains, ventilation airflow rates and use is relatively low on energy need (case 1 vs 4; case 2 vs 5; case 3 vs 6) compared to the climatic effect when comparing Nordic to Oceanic cases (e.g. case 4 vs 5). However, comparison of Estonian and Finnish calculations shows that there is little difference between the Nordic cases (cases 2, 3, 5, 6). By looking at the average temperatures, the Finnish TRY suggests higher heating need due to relatively lower wintertime temperatures. By comparing the results with Estonian calculation (case 5 vs 6) however shows the opposite, illustrating the impact of different internal heat gains and ventilation rates. As the differences in Estonian and Finnish TRYs are negligible, the following analysis is conducted by using the Estonian TRY also for Finnish cases for the comparative calculations.

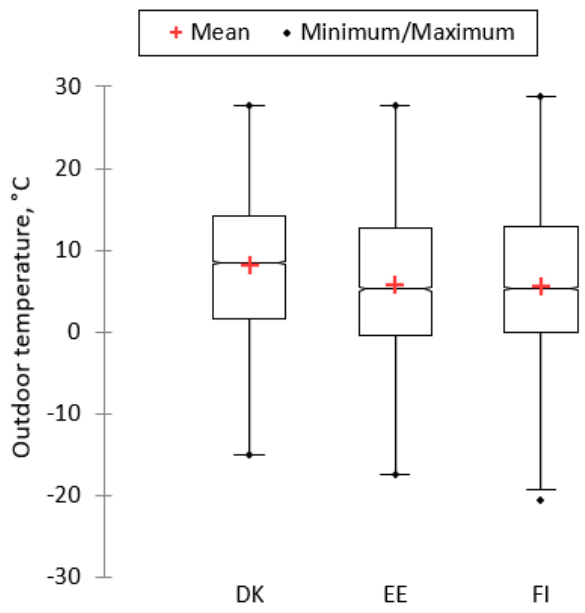

Figure 6. Box plot of annual hourly average dry bulb temperatures from Finnish (FI), Estonian (EE) and Danish (DK) TRYs.

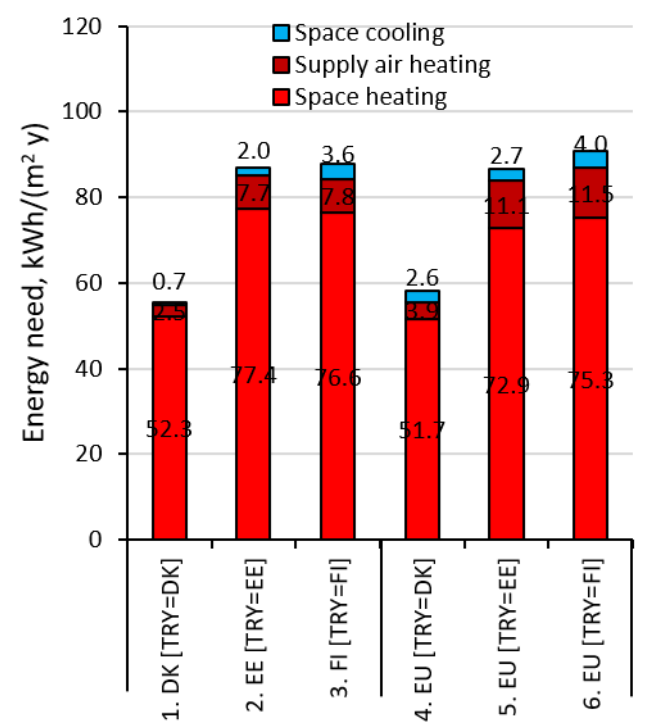

Figure 7. Comparison of annual simulated energy need for heating and cooling with different calculation methodology and TRY climates. Simulated using standardised (EU), Danish (DK), Estonian (EE) and Finnish (FI) methodology and input data. 


\subsection{Monthly and hourly calculations}

The calculated annual energy need using hourly dynamic calculations with IDA ICE software showed $3 \%$ lower heating energy and $23 \%$ lower cooling energy need resulting in $10 \%$ lower primary energy value compared to results acquired with the $\mathrm{Be} 18$ tool in the case of the single-family building (Figure 8).

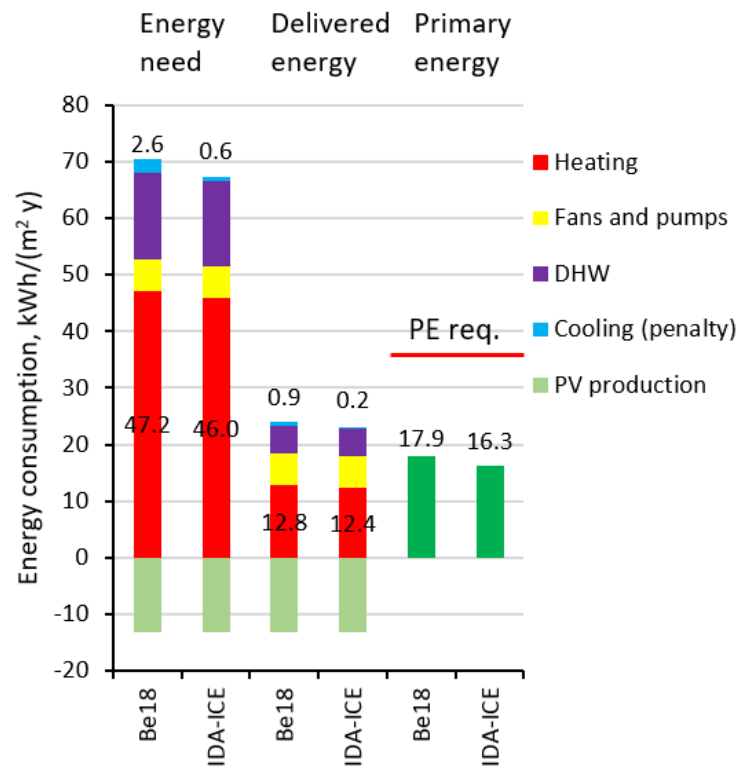

Figure 8. Comparison of reference single-family house energy performance calculation results calculated with Be18 (monthly calculations) and IDA ICE (hourly dynamic simulations) according to Danish methodology.

\subsection{Energy need and delivered energy}

Besides the climatic differences, internal heat gains, building usage rates and ventilation air flow rates, building energy consumption is influenced by the HVAC system efficiencies and distribution losses. Based on the specific methodology, these values are either calculated using standardised methods or given by pre-determined values. The following section gives an overview of the resulting differences between the methodologies used.

\subsubsection{Single-family house simulation results}

Figure 9 illustrates the energy needs of the reference single family house calculated according to the EU and national methodologies. The energy simulations are conducted with the initial building parameters (e.g. envelope, HVAC etc.) and only increasing or decreasing the required $\mathrm{PV}$ energy production to meet the national NZEB requirements. Calculation results with the Estonian methodology however show that the building with the initial configuration does not meet the required energy performance level as it is required to achieve a minimum energy efficiency level (EPC Class B) also without accounting the on-site produced renewable energy. This is due to the envelope elements thermal performance parameters, which are set to meet the requirements of relatively milder climate conditions of Denmark. Despite the latter, it is shown how much PV electricity production in principle would be needed to achieve the Estonian NZEB level for the Danish reference building.

Due to the passive measures to minimize the risk of summertime overheating, the penalty for accounted cooling energy was negligible compared to energy needs for other systems, e.g. in the Danish case, the cooling energy need was $0.6 \mathrm{kWh} /\left(\mathrm{m}^{2} \cdot \mathrm{y}\right)$, whereas in contrast the heating need was $46 \mathrm{kWh} /\left(\mathrm{m}^{2} \cdot \mathrm{y}\right)$.

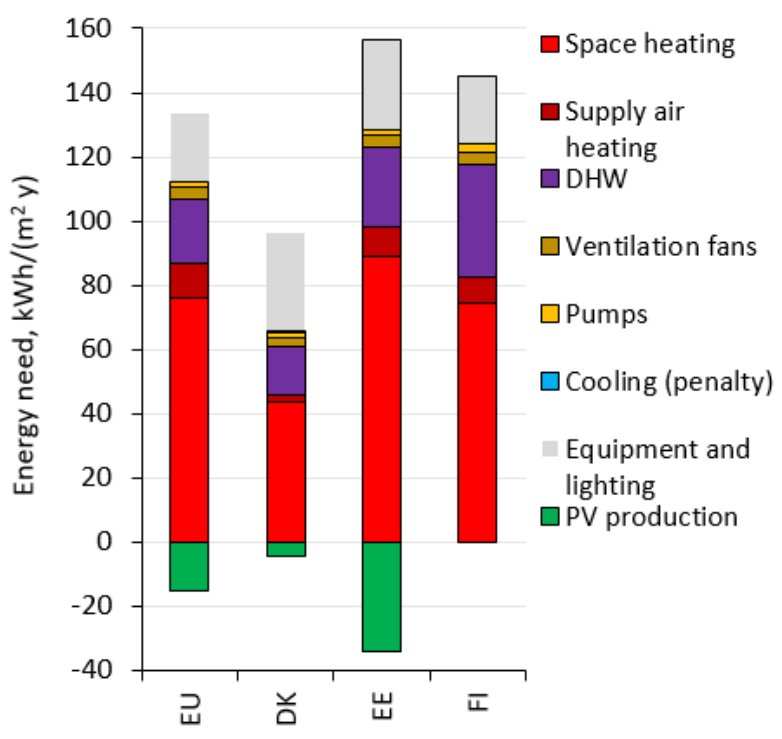

Figure 9. Annual energy needs of the reference single-family house. PV energy production is added to meet the national NZEB requirements. Simulated according to standardised (EU), Danish (DK), Estonian (EE) and Finnish (FI) methodology.

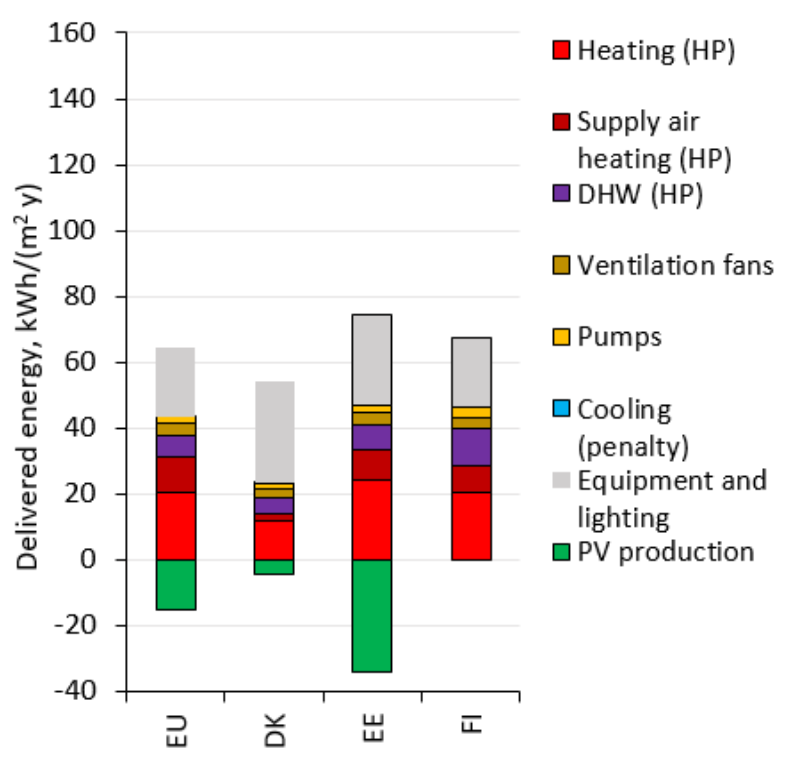

Figure 10. Annual delivered energy of the reference singlefamily house. PV energy production is added to meet the national NZEB requirements. Simulated according to standardised (EU), Danish (DK), Estonian (EE) and Finnish (FI) methodology. 
In case of Estonia (EE) and Finland (FI), the energy needs for equipment, appliances (plug loads) and lighting are accounted in the PE calculation. This means that for from the total building energy needs, roughly $1 / 3$ of PE, in case of EE and FI, is pre-determined by the methodology as it sets fixed values for auxiliary electricity, DWH and equipment. In case of DK and the standardised EU, the fractions are approx. 1/4 and 1/5 respectively for this house.

The delivered energy results in Figure 10 illustrate how much energy is needed annually to achieve the required indoor climate conditions with the designed HVAC systems. Furthermore, it shows how much onsite onside PV production is needed to meet the NZEB requirements.

\subsubsection{Apartment building simulation results}

Figure 11 shows the energy need and Figure 12 the delivered energy of the reference apartment building. The initial building configuration, when calculated using national methodology, did not require on-site renewable energy production in the Danish and Finnish case to fulfil the NZEB PE level requirement.

Because all countries have similar efficiencies and distribution loss coefficients for district heating-based heating system and domestic hot water production, there is little difference between energy need and delivered energy in all cases. As was the case with the singlefamily house, the highest DHW consumption for apartment buildings is also defined in the Finnish regulations, followed by Estonian, EC standardized and Danish. DHW energy need was also the highest in Finnish and Estonian cases.

The electricity consumption in apartment the building for equipment and lighting - contributing to the internal heat gains - has similar values for the analysed regulations: Danish methodology uses the highest values followed by Estonian, Finnish and standardised methodology-based values.

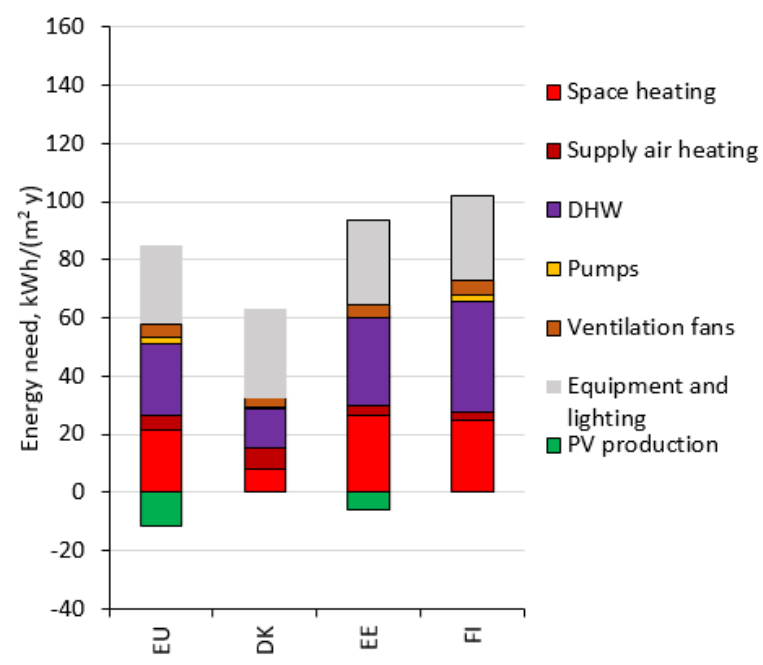

Figure 11. Annual energy needs of the reference apartment building. PV energy production is added to meet the national NZEB requirements. Calculated according to standardised (EU), Danish (DK), Estonian (EE) and Finnish (FI) methodology.

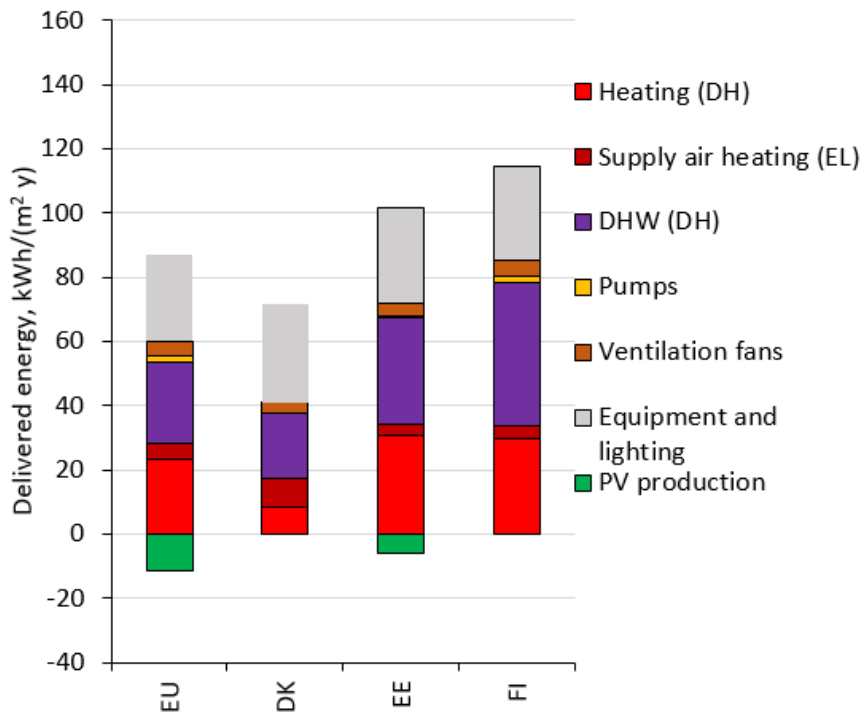

Figure 12. Annual delivered energy of the reference apartment building. PV energy production is added to meet the national NZEB requirements. Simulated according to standardised (EU), Danish (DK), Estonian (EE) and Finnish (FI) methodology.

\subsection{National NZEB levels comparison}

\subsubsection{Single-family house PE performance}

Following the Danish requirements, installation of $12 \mathrm{~m}^{2}$ of PV (Figure 13, case 1) sets the building on the BR 2018 voluntary "low-energy" line $[\mathrm{PE} \leq 27$ $\left.\mathrm{kWh} /\left(\mathrm{m}^{2} \mathrm{y}\right)\right]$. The NZEB requirement, $\mathrm{PE} \leq 36.1$ $\mathrm{kWh} /\left(\mathrm{m}^{2} \mathrm{y}\right)$, is achieved with $5 \mathrm{~m}^{2}$ of PV panels (case 2). The initial design installation of the house with $24 \mathrm{~m}^{2}$ of PV produces a surplus of $73 \% \mathrm{PV}$ energy compared with the amount required for NZEB. However, when calculating the building with $5 \mathrm{~m}^{2}$ of PV using the EU standardized input data while leaving technical systems, envelope, and other building parameters initial (case 3), the building does not achieve the recommended energy performance level (Oceanic zone) of PE $\leq 30$ $\mathrm{kWh} /\left(\mathrm{m}^{2} \cdot \mathrm{y}\right)$, but requiring additional $16 \mathrm{~m}^{2}$ of PV panels (case 5). This means that even the amount of PV required for Danish low energy level is not sufficient to achieve EC level (case 4). In this case also the EC recommendation of $\mathrm{PE}$ without renewable energy production (Oceanic zone) $\mathrm{PE} \leq 65 \mathrm{kWh} /\left(\mathrm{m}^{2} \cdot \mathrm{y}\right)$ is not fulfilled. Using the Danish calculation standard and tool, show an energy need of $47.4 \mathrm{kWh} / \mathrm{m}^{2} \mathrm{yr}$ without $\mathrm{PV}$.

The PE recommendation for Nordic zone, $\mathrm{PE} \leq 65$ $\mathrm{kWh} /\left(\mathrm{m}^{2} \cdot \mathrm{y}\right)$, is met with $18.5 \mathrm{~m}^{2}$ of PV (case 6). This amount however is not sufficient to achieve the Estonian NZEB performance level (case 7). Even the initial installation of $24 \mathrm{~m}^{2} \mathrm{PV}$ panels (case 8 ) is not sufficient to meet the threshold of $\mathrm{PE} \leq 120 \mathrm{kWh} /\left(\mathrm{m}^{2} \cdot \mathrm{y}\right)$. It would require $39 \mathrm{~m}^{2}$ of $\mathrm{PV}$ panels in total (case 9) for the building to qualify in Estonia as NZEB (energy performance class A). The higher need for PV electricity production in the Estonian cases at one hand is because only the fraction of produced energy that is used in the building is accounted in energy calculation. 


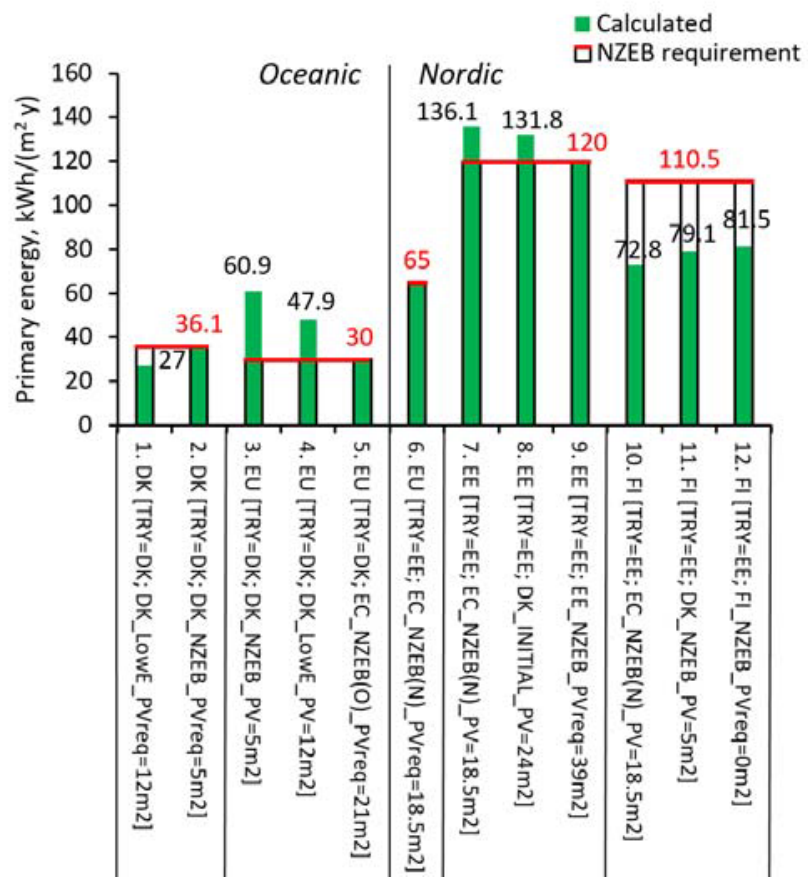

Figure 13. Annual PE consumption of the reference singlefamily house. PV energy production is added or removed to meet NZEB requirements. Code example: DK [TRY=DK; DK_LowE_PVreq $=12 \mathrm{~m}^{2}$ ] - Danish methodology [Simulated with Danish TRY, meets Danish Low energy threshold with $24 \mathrm{~m}^{2}$ of installed PV].

Even with the added PV production, the building does not meet all the requirements - it would need to comply with energy performance class B without accounting the on-site renewable energy production; that is $\mathrm{PE} \leq 140$ $\mathrm{kWh} /\left(\mathrm{m}^{2} \cdot \mathrm{y}\right)$. This requirement however is not fulfilled, meaning that, for example, the thermal or technical systems performance of the building envelope should be improved. This is also expected when moving the initial Oceanic design to a colder climate. In contrast, the Finnish NZEB requirements were met even without local renewable energy production (case 12). It must be emphasised that besides methodological and climatic differences, the PE performance results are largely influenced by the national PE factors. As the reference building utilises heat pump system for space, ventilation air heating, and DHW, the PE consist of only electricity consumption, highlighting the impact of the nationally different electricity PE factors.

\subsubsection{Apartment building PE performance}

The reference apartment building (designed for Nordic climate and including RE production to meet Estonian NZEB requirement) calculated according to the Danish building regulations met the NZEB requirement of $\mathrm{PE} \leq 30.2 \mathrm{kWh} /\left(\mathrm{m}^{2} \cdot \mathrm{y}\right)$ quite easily with total $\mathrm{PE}$ of $9.9 \mathrm{kWh} /\left(\mathrm{m}^{2} \cdot \mathrm{y}\right)$ (Figure 14 , case 1$)$, which is also expected due to climatic differences. Even without PV production the building performance surpasses the required $\mathrm{PE}$ threshold by only $0.7 \mathrm{kWh} /\left(\mathrm{m}^{2} \cdot \mathrm{y}\right)$ (case 2$)$.

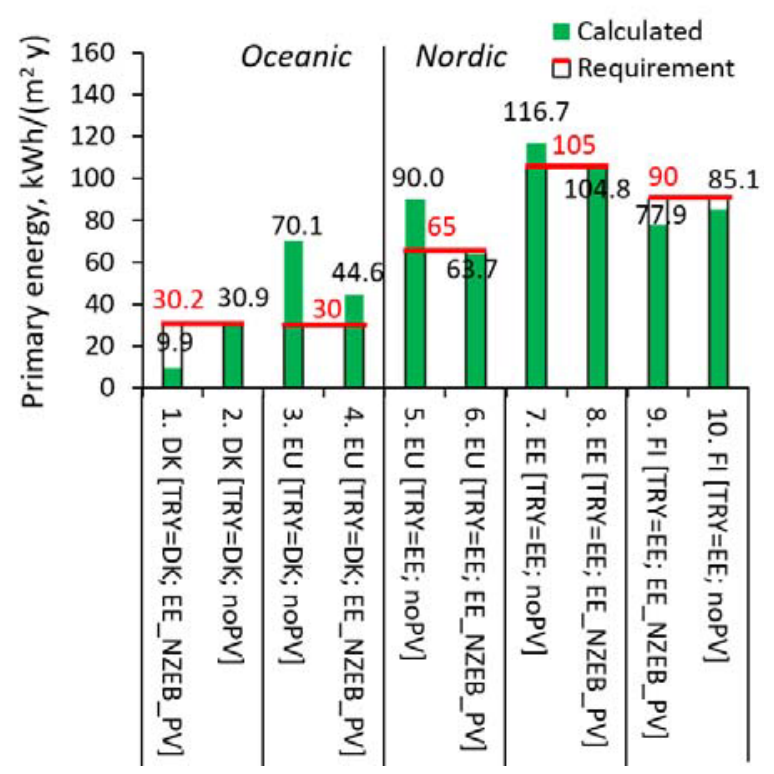

Figure 14. Annual PE consumption of the reference apartment building. PV energy production is added to meet NZEB requirements. Code example: DK [DK_LowE; TRY=DK; $\mathrm{PV}=24 \mathrm{~m}^{2}$ ] - Danish methodology [Danish Low energy threshold; Danish TRY and $24 \mathrm{~m}^{2}$ of installed PV].

The reference apartment building without PV production (case 3 ) is far to meet the EC recommended maximum values for NZEB and exceeds the EC PE recommended limit for building $\mathrm{PE}$ consumption without on-site renewable energy production $\mathrm{PE} \leq 65$ $\mathrm{kWh} /\left(\mathrm{m}^{2} \cdot \mathrm{y}\right)$. The reference building with $\mathrm{PV}$ does also not meet EC NZEB maximum value (case 4, calculated with EU standardised input data). This illustrates the relatively high performance level recommendation for EC Oceanic zone, considering the building is initially designed for Nordic climate. Basically, the results show that EC Oceanic NZEB is not achievable with district heating with EU default primary energy factor because the roof of the reference building is fully covered with $\mathrm{PV}$ and it is practically impossible to further improve the energy performance.

Calculation results using the EU standardised input data for Nordic climate (case 4) position the building exactly to the EC recommended level for PE without accounting RE production, that is $\mathrm{PE} \leq 90 \mathrm{kWh} /\left(\mathrm{m}^{2} \cdot \mathrm{y}\right)$ (case 5). Also, the EC PE recommendation with RES is fulfilled (case 6). As the building is designed as NZEB in Estonia, it is also designed to meet the national NZEB requirements with initial PV production (case 8 ) and the required low energy (energy class B) requirements (case 7). As was the case with Finnish requirements for detached houses, the apartment building fulfils the requirements also without on-site renewable energy production as well (cases 9 and 10). The results indicate that the Estonian requirements match the EC recommendations if the building utilises district heating energy. It can also be stated that buildings designed to comply with Finnish building regulations, the PE requirements would not meet the EC PE recommended levels. 


\section{Conclusions}

In case of the Oceanic zone, the EC recommendations for residential NZEB PE appear to require relatively higher energy performance compared to the Nordic zone recommendations. This is illustrated with the case of Denmark, located in colder part of the Oceanic zone. A highly insulated reference apartment building with district heating and PV fulfilling EC Nordic NZEB recommendation exceeded EC Oceanic NZEB recommendation. At the same time, a reference detached house with ground source heat pump and extensive PV installation was capable to meet EC Oceanic NZEB recommendation. However, this performance level clearly exceeded Danish NZEB and Low Energy. However, more calculations are needed to provide a more suitable PE limit value for the Oceanic climate zone.

In the Nordic climate zone, Estonian NZEB requirements complied very closely to EC Nordic NZEB recommendation. Finnish NZEB requirements were less strict and did not fulfilled EC Nordic NZEB recommendation.

The study illustrates the difference of having two sets of requirements: with and without renewable energy production, as is the case for Denmark and Estonia. Denmark has set the maximum amount of RE allowed to account in the PE calculation, requiring the building to achieve a sufficient level of performance by means of envelope elements and HVAC systems, reducing the energy consumption of the building. In Estonia there are PE requirements for the building without accounting onsite RE production as well as for the building including RES. Finland however has only requirements for PE with RES energy production included.

Limitations of the study should be considered when broadening the implications of the results, e.g., only two buildings were analysed and by moving buildings from one country to another without changing thermal insulation. The latter is especially illustrated between relatively warmer Oceanic climate and colder Nordic climates. It can be estimated that the optimal insulation thickness increases slightly when moving from Denmark to Estonia and vice versa, which effects need to be analysed in future studies to end up with fully fair comparison.

The main differences in energy performance calculation results between the analysed countries lie in the methodology, included energy flows and climatic conditions - expressed as test reference year climate data. To some extent, the calculation results are also influenced by differences in building usage rates, internal heat gains, temperature set-points, ventilation airflow rates and HVAC systems distribution losses. The differences in PE factors and NZEB PE limits have high influence on HVAC systems selection, thermal insulation levels and on-site renewable energy systems implementation. The calculations conducted with EU standard-based input data under Nordic climatic conditions show that importing initial building designs from Oceanic climate countries to Nordic climate countries require changes to building envelope insulation.

This research was supported by the Nordic Energy Research, The joint Baltic-Nordic Energy Research programme (Project No.: 96752), by the Estonian Centre of Excellence in Zero Energy and Resource Efficient Smart Buildings and Districts, ZEBE, grant 2014-2020.4.01.15-0016 funded by the European Regional Development Fund and by the European Commission through the $\mathrm{H} 2020$ project Finest Twins (grant No. 856602).

\section{References}

[1] C. Tanasa, D. Dan, C. Becchio, S. P. Corgnati, and V. Stoian, "Cost-optimal and indoor environmental quality assessment for residential buildings towards EU long-term climate targets," Energy Sustain Dev, vol. 59, pp. 49-61, 2020/12/01/2020, doi: https://doi.org/10.1016/j.esd.2020.09.002.

[2] M. Economidou, V. Todeschi, P. Bertoldi, D. D'Agostino, P. Zangheri, and L. Castellazzi, "Review of 50 years of EU energy efficiency policies for buildings," Energ Buildings, vol. 225, p. 110322, 2020/10/15/ 2020, doi: https://doi.org/10.1016/j.enbuild.2020.110322.

[3] (2018). Directive (EU) 2018/844 of the European Parliament and of the Council of 30 May 2018 amending Directive 2010/31/EU on the energy performance of buildings and Directive 2012/27/EU on energy efficiency (recast). [Online] Available: https://eurlex.europa.eu/eli/dir/2018/844/oj

[4] "Commission Recommendation (EU) $2016 / 1318$ of 29 July 2016 on guidelines for the promotion of nearly zero-energy buildings and best practices to ensure that, by 2020, all new buildings are nearly zero-energy buildings," vol. L 208, pp. 46-57. [Online]. Available:

http://data.europa.eu/eli/reco/2016/1318/oj

[5] K. Ahmed, G. Yoon, M. Ukai, and J. Kurnitski, "How to compare energy performance requirements of Japanese and European office buildings," E3S Web Conf., vol. 111, p. 03038, 2019. [Online]. Available:

https://doi.org/10.1051/e3sconf/201911103038.

[6] CEN. EN 16798-1:2019. Energy performance of buildings. Ventilation for buildings. Indoor environmental input parameters for design and assessment of energy performance of buildings addressing indoor air quality, thermal environment, lighting and acoustics. Module M1-6, CEN, 2019. [Online]. Available: https://standards.cen.eu/dyn/www/f?p=204:110 $: 0$

[7] (2020). Estonian Government Ordinance No. 63: "Hoone energiatõhususe miinimumnõuded" [Minimum requirements for buildings energy efficiency] (in Estonain), RT I, 2018, redacted 10.07.2020. [Online] 
Available:

https://www.riigiteataja.ee/akt/122082019002? leiaKehtiv

[8] (2018). Danish Government Executive Order on building regulations 2018 (BR18) No. 1615 of 13 Dec. 2017. [Online] Available: https://bygningsreglementet.dk/

[9] (2017). Finnish Government Ordinance No 788/2017: Rakennuksissa käytettävien energiamuotojen kertoimien lukuarvoista [Numerical values of the coefficients for the forms of energy used in buildings] (in Finnish). [Online] Available: https://finlex.fi/fi/laki/alkup/2017/20170788

[10] J. Kurnitski, "Technical definition for nearly zero energy buildings," REHVA European HVAC Journal, vol. 2013, no. 3, pp. 22-28, 2013. [Online]. Available:

https://www.rehva.eu/rehvajournal/chapter/technical-definition-for-nearlyzero-energy-buildings.

[11] (2020). Estonian Government Ordinance No. 58: "Hoone energiatõhususe arvutamise metoodika" [Calculation methodology for building energy efficiency] (in Estonian), RT I, 2015, redacted 10.07.2020. [Online] Available: https://www.riigiteataja.ee/akt/107072020012? leiaKehtiv

[12] (2017). Finnish Government Ordinance No 1010/2017: Uuden rakennuksen energiatehokkuudesta [Energy efficiency of a new building] (in Finnish). [Online] Available: https://www.finlex.fi/fi/laki/alkup/2017/20171 $\underline{010}$
[13] (2018). National Building Code of Finland. Guide for calculation of building energy consumption and heating power demand. [Online] Available: https://ym.fi/rakentamismaaraykset

[14] SBi. "Be18 calculation program." Danish Building Research Institute.

https://sbi.dk/beregningsprogrammet/Pages/Hv ad-er-Be18.aspx (accessed 10 November, 2020).

[15] "Energimærkningsrapport [Energy labeling report] (in Danish)." Accessed: 12 December 2020. [Online]. Available: https://emoweb.dk/EMODigital/EMODigital.s vc/PdfDocument/311234802

[16] https://betoneks.ee/referentsid/ (accessed 10 December, 2020).

[17] IDA Indoor Climate and Energy (IDA ICE, version 4.8). (2020). Equa Simulations AB. [Online]. Available: www.equa.se

[18] K. Ahmed and J. Kurnitski, "New Equation for Optimal Insulation Dependency on the Climate for Office Buildings," Energies, vol. 14, no. 2, p. 321, 2021. [Online]. Available: https://www.mdpi.com/1996-1073/14/2/321. 